\title{
Designing a compatible model of share issue privatization for Tehran stock exchange (TSE) development
}

\author{
Mohammad Aram Bonyar ${ }^{\mathrm{a}^{*}}$, Fatemeh Pousti ${ }^{\mathrm{b}}$ and Corynne Jaffeux ${ }^{\mathrm{c}}$
}

${ }^{a}$ Université Montesquieu Bordeaux IV, Paris, France

${ }^{b}$ Faculty of Management Studies and Information Technology (FMIT), Jamia Hamdard University, New Delhi, India

${ }^{c}$ Université Montesquieu Bordeaux IV, Paris, France

\begin{tabular}{|c|c|}
\hline A R T I C L E I N F O & ABSTRACT \\
\hline $\begin{array}{l}\text { Article history: } \\
\text { Received October 1, } 2011 \\
\text { Received in Revised form } \\
\text { December, 10, } 2011 \\
\text { Accepted 12 December } 2011 \\
\text { Available online } \\
\text { 14 December } 2011 \\
\text { Keywords: } \\
\text { Privatization } \\
\text { Privatization Model } \\
\text { Share Issue Privatization } \\
\text { Tehran Stock Exchange (TSE) } \\
\text { Stock Market Development }\end{array}$ & $\begin{array}{l}\text { In this research, we conduct a reverse study to design a compatible model of share issue } \\
\text { privatization for Tehran stock exchange (TSE) development. Privatization and stock market } \\
\text { development are known as two representatives of economic growth. Governments use these } \\
\text { two economic means to achieve their development goals. In this study, the impact of share issue } \\
\text { privatization on stock market development is studied and an optimal model of share issue } \\
\text { privatization for Tehran stock exchange (TSE) development is introduced. To study the effect } \\
\text { of share issue privatization on key market development variables panel data of privatization } \\
\text { index(IPIX), transaction volume, turnover velocity ratio and closing price of each TSE listed } \\
\text { company are entered in co integration and error correction models (ECM) during March 2008- } \\
\text { June 2011. The result of statistical studies shows a significant relation between privatization } \\
\text { index (IPIX) growth and the growth of each of Tehran stock exchange development proxies. } \\
\text { Then to design a compatible model of share issue privatization for Tehran stock market } \\
\text { development, Delphi survey following Schmitt approach during } 4 \text { phases is implemented. }\end{array}$ \\
\hline
\end{tabular}

\section{Introduction}

The Privatization as a method of reallocating assets and functions from the public sector to the private sector appears to be a factor that could play a serious role in the quest for growth (Filipovic, 2005). Public offering of shares, or share issue privatization (SIP), involves the sale of some or a government's entire stake in an enterprise through public share offering. (Dezhbakhsh, 2004). All factors influencing development of stock markets are outcomes of programs, policies and decisions made in macroeconomic and political levels. Privatization as a tool for economic management is executed in various methods and different levels. Directly and indirectly, privatization efficiently helps stock market development and invigoration. The Article 44 of Iranian Constitution about privatization argues sale of some of the nationalized and state-owned enterprises to the private sector.

\footnotetext{
* Corresponding author. Tel. +982188784450-51

E-mail addresses: m.aram@aminib.com (M. Aram) 
The below table shows the most frequently used method of privatization in Iran is share issue privatization through Tehran stock market.

\section{Table 1}

Privatization method in Iran in terms of divestiture method

\begin{tabular}{|c|c|c|c|c|c|c|c|c|}
\hline \multicolumn{8}{|c|}{ Privatization in Terms of Divestiture Method } & \multirow[t]{2}{*}{$\begin{array}{l}\text { Total Value of } \\
\text { Privatizations } \\
\text { (USD Billion) }\end{array}$} \\
\hline Year & 2005 & 2006 & 2007 & 2008 & 2009 & 2010 & 2011 & \\
\hline Exchange (USD Billion) & 0.0453 & 2.4788 & 16.2399 & 19.4689 & 14.7143 & 4.0209 & 2.1902 & 59.1583 \\
\hline$\%$ of Aggregate Privatizations & $0.05 \%$ & $3 \%$ & $19 \%$ & $23 \%$ & $17 \%$ & $5 \%$ & $3 \%$ & $69.50 \%$ \\
\hline OTC(USD Billion) & - & - & - & - & 0.0311 & 2.5607 & 0.1342 & 2.726 \\
\hline$\%$ of Aggregate Privatizations & - & - & - & - & $0.04 \%$ & $3.01 \%$ & $0.16 \%$ & $3.20 \%$ \\
\hline Tender(USD Billion) & - & - & - & - & 0.2502 & 0.0642 & 0.0064 & 0.3208 \\
\hline$\%$ of Aggregate Privatizations & - & 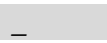 & & - & $0.29 \%$ & $0.08 \%$ & $0.01 \%$ & $0.38 \%$ \\
\hline Negotiation(USD Billion) & 0.0311 & 0.0602 & 8.7538 & 2.025 & 2.9067 & 7.904 & 1.2353 & 22.9161 \\
\hline$\%$ of Aggregate Privatizations & $0.04 \%$ & $0.07 \%$ & $10.28 \%$ & $2.38 \%$ & $3.41 \%$ & $9.29 \%$ & $1.45 \%$ & $26.92 \%$ \\
\hline $\begin{array}{l}\text { Total Value of Privatizations } \\
\text { (USD Billion) }\end{array}$ & 0.0764 & 2.539 & 24.9937 & 21.4939 & 17.9023 & 14.5498 & 3.5661 & 85.1212 \\
\hline$\%$ of Aggregate Privatizations & $0.09 \%$ & $2.98 \%$ & $29.36 \%$ & $25.25 \%$ & $21.03 \%$ & $17.09 \%$ & $4.19 \%$ & $100.00 \%$ \\
\hline
\end{tabular}

The purpose of this research is to design a compatible model for share issue privatization (SIP) of state owned enterprises (SOEs) in a way which leads to Tehran stock exchange (TSE) development. To achieve this objective, initial public offering price index (IPIX) is designed as a barometer to reflect price fluctuations of shares of 19 privatized companies in TSE. To reveal the positive impact of SIPs on TSE, the relation of IPIX and TSE development proxies is statistically considered by the use of E-Views software. To design the optimal model of share issue privatization through TSE, Delphi questionnaires in a two-stage process are distributed among privatization specialists in Iranian privatization organization (IPO), stock market specialists in securities and exchange organization of Iran (SEO), Tehran Stock Exchange (TSE) and professors of investment and finance. The outputs of survey are analyzed by the use of SSPS software.

The result of study shows a significant relation among TSE development proxies and, privatization IPOs index, IPIX. Then it suggests a share issue privatization model for TSE development. The organization of this paper is as follows. We first study privatization and privatization models. Then previous research works are considered. Methodology of research is presented in section 2.The results of statistical studies are presented in section 3. Discussions, concluding remarks, research limitations and recommendations are given in section 4 to summarize the contribution of this paper.

\subsection{Privatization Models}

In theory, privatization can result in economic gains, ever in cases where market failure may justify some level of government intervention. In practice, privatization, as an economic growth tools, has increased profitability and efficiency. For instance, Poland as the second most active privatizer among European countries reflects the country's much more robust rate of economic growth and greater financial dynamism as a the results of adapting privatization programs (The Privatization Barometere Report, 2010, pp. 3). Two decades of privatization appears to have changed the focus of the privatization debate from "whether to privatize" to" how to privatize". The most commonly used methods of privatization include public offering of shares or share issue privatization (SIP), private sale of enterprises, sale of enterprise assets to private investors and voucher method.

Public offering of shares, or share issue privatization (SIP), involves the sale of some or a government's entire stake in an enterprise through public share offering. The underwriter may use a fixed price or a tender to determine the initial share value. This method provides investment opportunity to a large class of citizens while also generating more revenue for the government. Its successful implementation requires professional investment bankers and an active stock market that 
many developing countries lack. Successful examples in developing countries include Brazil's Petrobras and Banco do Brasil; Chile's Chilquinta Electricity and Entel Telecom; Turkey's Teletas and Netas Telecommunication; Singapore's Airlines, DBS Bank, and Iron \& Steel Mills; Malaysia's MAS Airlines and Malaysia Shipping; and Sri Lanka's State Rubber.

The theoretical framework and the result of former researches show that, popularly, share issue privatization leads to boost the degree of liquidity as the main market development proxy (Jafari Seresht, 2010). In general, public sale of enterprises appears to have a good track record in Eastern Europe, and particularly in countries where private sector is relatively strong. This method has the potential to be successful in Iran as well because of Iran's long experience with free enterprise and the resolve of the government to expand private ownership through privatization. In addition, Iran has in place a system of property rights and a legal framework for corporate conduct. Therefore, public sale of companies through stock market (offering of shares) or auction appears to be the most appropriate method of privatization in Iran (Dezhbakhsh, 2004). In a research undertaken by Dalsenius (2007), " Effects of Stock Market Liquidity on Growth: Empirics and Theory", the market liquidity is examined and confirmed as a significant capital market development proxy in a sample comprises a group of developed and developing countries. Investors prefer markets with high degree of liquidity. Therefore, liquidity plays a vital role in market growth and development (IOSCO, 2007). Naceur et al. (2007) studied saving rate, participation of financial intermediaries and market liquidity of 12 countries in Middle East and north of Africa. They concluded that these factors play important roles in market development and market development, itself, has a crucial effect on economic growth (Naceur et al., 2007). The average initial public offering outside the United States of America reported in research papers written by Laurent et al. (1994), although differ substantially in different markets and times, but is less than \$ 15 million. In addition to being very large according to the standards of the shares offered by the private sector, share issue privatizations (SIPs) are the largest type of privatization through the securities market. Megginson (2001) report that the average size of 1526 assets sales of SOEs performed during 1977-2000 period is 290 million dollars (median 30.03 million dollars) compared with an average 799 million dollars (105 million median) for the 931 shares issue privatizations through the securities market.

The first company subject to privatization law, The National Iranian Copper Industry Corporation, enters into TSE in February 2007. During the 5 years time, market capitalization increased dramatically from 39.46 USD billion in February 2007 to 116.37 USD billion in June 2011, at the same time market value of privatization IPOs on the exchange also raised from 2.14 USD billion to 53.67 USD billion during this period. The TSE was reactivated during this time, partly to implement the public sale of government owned enterprises. The privatized companies constitute $46 \%$ of TSE market capitalization on June 2011. The number of share traded on the TSE becomes tripled over the time period February 2007- June 2011. The stock market popularly has maintained its growth, although at a more moderate pace. The TSE index (TEPIX) skyrocketed from around 9,836 to 25,214 during the February 2007- June 2011. A similar increase in the transaction volume suggests that the stock market is gaining the much-needed acceptability by a public that has too few choices for longterm investment.

\subsection{Privatization Process in Globe}

The theoretical sequence of privatization is not mentioned in previous researches. However, according to government of Pakistan, the followings are introduced as general privatization process in globe.

- Identification and an entity for privatization

- Cabinet committee of privatization (CCOP)/ cabinet approval 
- Appointment of financial advisor (FA) for major transaction(s) with approval of privatization cabinet (PC) board

- Appointment of valuator where FA is not hired

- Due diligence by FA/valuator

- Privatization strategy

- Restructuring, sectoral/ regulatory reforms if required

- Expressions of interest (EOI)

- Screening-statement of qualification (SOQ)

- Pre-qualification

- Due diligence by potential bidder(s)

- Valuation approved by PC board and CCOP

- Pre-bid conference(s)

- Bidding process approval by board and CCOP

- Open bidding: media invited to observe

- Board and CCOP approve price and bidder

- Letter of acceptance to successful bidder

- Management transfer (through execution of share purchase agreement/asset sale agreement) after $100 \%$ receipt of payment.

\subsection{Theoretical Framework of Share Issue Privatization Process in Globe}

In accordance with finance literature, the global theoretical framework of share issue privatization is as below:

- Preparation,

- Due Diligence: financial, legal and technical,

- Valuation,

- Issuing Registration Report,

- Prospectus,

- Marketing: domestic, international,

- Dual Listing,

- IPO Price Discovery: there are three different methods namely book building, fixed price and auction. Auction itself is of two main methods; Dutch and England.

- Market Making: In some countries concentrated market making is in use and in the other nonconcentrated. Each of market making methods can be quote driven or order driven.

\section{Methodology of research}

To reflect the impact of privatization IPOs on Tehran stock exchange (TSE), initial public offering price index (IPIX) is computed. This index is calculated on the basis of Laspeyres index principles and presents the changes in privatization IPOs during research period. Then, to estimate the relation of share issue privatizations on Tehran stock exchange, some of market development proxies (transaction volume, turn over velocity ratio indicating market liquidity, Tehran stock market price index (TEPIX) and closing price) are used. We tested our research hypotheses using co integration and error correction models. To increase accuracy of study, both panel data and time series of data are entered into econometric models.

Afterwards to design a compatible model of share issue privatization for Tehran stock market development a two round Delphi survey following Schemitt approach in 4 phases was conducted. A sample of 38 financial and economic specialists was selected from experts in securities and exchange organization of Iran (SEO), Tehran stock exchange (TSE), Iranian privatization organization (IPO), 
Investment banks and finance professors. They all hold master's and doctorate degrees in their disciplines. Prospective participates understood that they would complete two rounds of surveys in one month interval and the study was conducted during 2008-2011. In the beginning, participants received through mail the first questionnaire comprising questions about the relation of share issue privatization and Tehran stock market development and actions during share issue privatization contributing Tehran stock market development. After one month, the second questionnaire was mailed to them, comprising questions about the sequence and degree of importance of share issue privatization steps for Tehran stock market development.

Method of preparation of data and variables, problem discussion, econometric models, research hypotheses and the results of statistical tests are precisely presented in tables given below.

\subsection{Research variables}

Table 2

Research variables along with their explanations

\begin{tabular}{|c|c|c|}
\hline Variables & Formula & Comment \\
\hline TEPIX & Index Level=Base level $\times \frac{\sum_{\mathrm{i}=1}^{\mathrm{n}} \mathrm{X}_{\mathrm{i}} \times \text { No si } \times \text { cpi } \times \mathrm{ffi}}{\mathrm{b} \times \operatorname{adj} 1}$ & $\begin{array}{l}\text { According to } \\
\text { Laspeyers } \\
\text { principle }\end{array}$ \\
\hline IPIX & Index $=\frac{\sum_{i=1}^{n} p_{i} q_{i}}{\text { Base }} \times 100$ & $\begin{array}{l}\text { According to } \\
\text { Laspeyers } \\
\text { principle }\end{array}$ \\
\hline $\begin{array}{c}\text { Turn Over } \\
\text { Velocity Ration }\end{array}$ & Turn over velocity ratio $=\frac{\text { Monthly EOB domestic share turn over }}{\text { Month end domestic market capitalization }} \times 12$ & $\begin{array}{l}\text { World } \\
\text { Federation of } \\
\text { Exchange }\end{array}$ \\
\hline $\begin{array}{l}\text { Transaction } \\
\text { Volume }\end{array}$ & - & $\begin{array}{l}\text { Number of } \\
\text { Shares Traded } \\
\text { During A } \\
\text { Working Day }\end{array}$ \\
\hline Price Closing & VWAP $=\frac{\sum \text { Number of share traded in each transaction } \times \text { Share price in each transaction }}{\text { Total Number of share traded during a working day }}$ & $\begin{array}{l}\text { Weighted } \\
\text { Average of } \\
\text { Prices During a } \\
\text { Working Day }\end{array}$ \\
\hline
\end{tabular}

\section{Table 3}

Different approaches along with their methods of evaluation

\begin{tabular}{|c|c|c|}
\hline \multicolumn{2}{|r|}{ Approaches } & Panel Data \\
\hline & Econometric Models & Co integration - Error correction Model (ECM) \\
\hline & Data & Simple Data \\
\hline \multirow{4}{*}{ Research Variables } & Dependent & Initial Public Offering Price Index(IPIX) \\
\hline & & Closing Price of each TSE Listed Company \\
\hline & Independent & Turn over Velocity Ratio of each TSE Listed Company \\
\hline & & Transaction Volume of Each TSE Listed Company \\
\hline Research Hypotheses & & Results \\
\hline 1st hypothesis & $\begin{array}{l}\text { IPIX growth positively affects closing } \\
\text { price }\end{array}$ & Accepted \\
\hline 2nd hypothesis & $\begin{array}{l}\text { IPIX growth positively affects TSE } \\
\text { transaction volume }\end{array}$ & Accepted \\
\hline 3rd hypothesis & $\begin{array}{l}\text { IPIX growth positively affects TSE } \\
\text { liquidity }\end{array}$ & Accepted \\
\hline
\end{tabular}




\section{Statistical Analysis and Results}

\subsection{Privatization Index and TSE Market Development Proxies}

In this section of research, to consider the impact of privatization index (IPIX) on key market variables; closing price, transaction volume and velocity of transactions, during March 2008 till June2011, panel data of 202 companies are entered into model. Table 4 demonstrates the description of the variable used in this paper.

Table 4

Variable description using panel data (Row Data)

\begin{tabular}{lcccc}
\hline & Closing Price & Trade volume & Velocity Ratio & IPIX \\
\hline Mean & 5745.906 & 489656.3 & 0.000337 & 1314.823 \\
Median & 3680.333 & 43336.62 & $7.49 E-06$ & 1221.530 \\
Maximum & 31291.23 & 27162402 & 0.034836 & 2262.692 \\
Minimum & 1.000000 & 10.00000 & 0.000000 & 878.7977 \\
Standard deviation & 5532.728 & 1353689. & 0.001913 & 341.1391 \\
Skewness & 1.700276 & 7.006868 & 13.61713 & 1.037690 \\
Kurtosis & 5.958681 & 77.15236 & 214.3996 & 3.576585 \\
Jarque-Bera & 4792.400 & 1343535. & 14912889 & 1522.966 \\
Probability & 0.000000 & 0.000000 & 0.000000 & 0.000000 \\
\hline
\end{tabular}

\subsection{Testing for Unit Roots in Panel Data}

According to results of unit root test, all of the variables in their level have unit roots. However, they become stationary after differentiation. To consider the interrelation among non-stationary variables, co integration model shall be used. To this end, the below hypotheses are tested.

\subsection{Research Hypotheses}

First Hypothesis: Privatization Index (IPIX) Growth Positively Affects Closing Price

Estimation of a vector auto regression model and the number of optimal lags are the steps shall be taken before estimating a co integrated model. The vector auto regression model for the first hypothesis is as below:

Closing Price $_{\mathrm{i}, \mathrm{t}}=c_{1}+\sum_{i=1}^{p}$ Last Price $_{i, t-i}+\sum_{i=1}^{p} I P I X_{i, t-i}+\varepsilon_{\text {Last Price }}$

Estimation of the optimal number of lags in the above auto regression model makes it possible to compute the co integration model by the number of lags. Presence of long-run relationship between two variables is already approved. So, co integration model of closing price and IPIX can be estimated. The results of estimation with evaluation of adjustment factor are as below:

$I P I X_{i, t}=c_{2}+\sum_{i=1}^{p} I P I X_{i, t-i}+\sum_{i=1}^{p}$ Last $_{\text {Price }}$ it,-i $+\varepsilon_{\text {IPIXt }}$

$\Delta$ Last Price $_{\mathrm{t}}=\alpha_{1}$ (Last Price $\left._{\mathrm{i}, \mathrm{t}-1}-\beta I p x_{i, t-1}\right)+\sum_{i=1}^{10} \theta_{1 i}^{*} \Delta$ Last Price $_{\mathrm{i}, \mathrm{t}-\mathrm{i}}+\sum_{i=1}^{10} \varphi_{1 i}^{*} \Delta I p x_{i, t-i}+\varepsilon_{\text {Last Pricei }, \mathrm{t}}$

$\Delta I p x_{\mathrm{i}, \mathrm{t}}=\alpha_{2}\left(\right.$ Last Price $\left._{\mathrm{i}, \mathrm{t}-\mathrm{1}}-\beta I p x_{i, t-1}\right)+\sum_{i=1}^{10} \theta_{2 i}^{*} \Delta$ Last Price $_{\mathrm{i}, \mathrm{t}-\mathrm{i}}+\sum_{i=1}^{10} \varphi_{2 i}^{*} \Delta \operatorname{Ipx_{i,t-i}}+\varepsilon_{\mathrm{Ipxti}, \mathrm{t}}$

Estimation of above error correction model is in Table 5 as follows, 
Table 5

Estimation of error correction model

\begin{tabular}{ccccccc}
\hline variable & co integration equation & D(IPIX(-1)) & D(IPIX(-2)) & D(IPIX(-3)) & D(IPIX(-4)) & D(IPIX(-5)) \\
\hline coefficient & -0.001008 & 3.012224 & -0.770375 & 3.035218 & 0.388810 & -0.010185 \\
t- statistic & {$[-4.97430]$} & {$[5.15382]$} & {$[-1.43715]$} & {$[6.23009]$} & {$[0.68221]$} & {$[-0.01961]$} \\
variable & D(IPIX(-6)) & D(IPIX(-7)) & D(IPIX(-8)) & D(IPIX(-9)) & D(IPIX(-10)) & C \\
coefficient & -0.186879 & -0.649452 & -0.673337 & -0.948648 & -0.316285 & 350.4348 \\
t- statistic & {$[-0.40993]$} & {$[-1.55667]$} & {$[-1.61972]$} & {$[-2.58633]$} & {$[-0.86729]$} & {$[5.89675]$} \\
\hline
\end{tabular}

The quantity of coefficient of deviation from equilibrium path is equal to -0.001 . This is statistically significant. It means; approximately $0.1 \%$ is deducted from deviation in equilibrium path of two variables in each period. Level of Significance of this coefficient tells us those two variables reach to an equilibrium path in long-run. The equation of long-run equilibrium relation of two variables (IPIX and Closing Price) is shown hereunder:

\section{Table 6}

Long-run Relation of IPIX \& Closing Price

\begin{tabular}{ccc}
\hline variable & IPIX(-1) & C \\
\hline coefficient & 1164.205 & 1541953 \\
t- statistic & {$[20.7951]$} & \\
\hline
\end{tabular}

As it can be seen from calculated quantities related to long-term relation of two variables, IPIX has significant positive effect on closing price of TSE listed companies during research period.

Second Hypothesis: Privatization Index (IPIX) Growth Positively Affects Transaction Volume

Estimation of a vector auto regression model and the number of optimal lags are the steps shall be taken before estimating a co integrated model. The vector auto regression model for the second hypothesis is as below:

$$
I P I X_{i, t}=c_{2}+\sum_{i=1}^{p} I P I X_{i, t-i}+\sum_{i=1}^{p} \text { Transaction volume } \mathrm{i}_{\mathrm{t}, \mathrm{-i}}+\varepsilon_{\text {IPIXt }}
$$

Transaction volume $\mathrm{i}_{\mathrm{i}, \mathrm{t}}=c_{1}+\sum_{i=1}^{p}$ Transaction volume $_{\mathrm{i},-\mathrm{i}}+\sum_{i=1}^{p} \operatorname{Ipx_{i,t-i}}+\varepsilon_{\text {Transaction volume }}$

Table 7

Estimation of Error Correction Model (ECM)

\begin{tabular}{ccccccccc}
\hline variable & $\begin{array}{c}\text { co integration } \\
\text { equation }\end{array}$ & $\mathrm{D}(\mathrm{IPIX}(-1))$ & $\mathrm{D}(\mathrm{IPIX}(-2))$ & $\mathrm{D}(\mathrm{IPIX}(-3))$ & $\mathrm{D}(\mathrm{IPIX}(-4))$ & $\mathrm{D}(\mathrm{IPIX}(-5))$ & variable & $\mathrm{C}$ \\
\hline coefficient & -0.320672 & 693.5823 & 364.1125 & -479.8255 & 543.0122 & -276.7584 & coefficient & -20270.02 \\
t- statistic & {$[-15.5193]$} & {$[4.35042]$} & {$[1.97157]$} & {$[-2.52104]$} & {$[2.74348]$} & {$[-1.65612]$} & $\mathrm{t}$ - statistic & {$[-1.35399]$} \\
\hline
\end{tabular}

The quantity of coefficient of deviation from equilibrium path is equal to -0 . 32 . This is statistically significant. It means; approximately $0.32 \%$ is deducted from deviation in equilibrium path of two variables in each period. Level of significance of this coefficient tells us these two variables reach to an equilibrium path in long-run. The equation of long-run equilibrium relation of two variables (IPIX and Transaction volume) is shown hereunder:

\section{Table 8}

Long- run Relation of IPIX \& Transaction Volume

\begin{tabular}{cccc}
\hline variable & IPIX(-1) & @TREND & C \\
\hline coefficient & 358.9351 & 28.81085 & 117167.7 \\
t- statistic & {$[-1.92620]$} & {$[-1.61326]$} & \\
\hline
\end{tabular}


As it can be seen from calculated quantities related to long-term relation of two variables, IPIX has significant positive effect on transaction volume of TSE listed companies during research period.

Third Hypothesis: Privatization Index (IPIX) Growth Positively Affects TSE Liquidity

Estimation of a vector auto regression model and the number of optimal lags are the steps shall be taken before estimating a co integrated model. The vector auto regression model for the third hypothesis is as below:

$$
\begin{aligned}
& \text { Velocity Ratio }_{\mathrm{i}, \mathrm{t}}=c_{1}+\sum_{i=1}^{p} \text { Velocity Ratio }_{\mathrm{i}, \mathrm{t- \textrm {i }}}+\sum_{i=1}^{p} \operatorname{Ipx}_{i, t-i}+\varepsilon_{\text {Velocity Ration }} \\
& \text { IPIX }_{\mathrm{i}, \mathrm{t}}=c_{2}+\sum_{i=1}^{p} I P I X_{\mathrm{i}, \mathrm{t}-\mathrm{i}}+\sum_{i=1}^{p} \text { Velocity Ratio } \\
& i, t-i
\end{aligned}
$$

Estimation of above error correction model is summarized in Table 9 as follows,

\section{Table 9}

Estimation of Error Correction Model (ECM)

\begin{tabular}{lcccccccc}
\hline variable & $\begin{array}{c}\text { co integration } \\
\text { equation }\end{array}$ & $\mathrm{D}(\mathrm{IPIX}(-1))$ & $\mathrm{D}(\mathrm{IPIX}(-2))$ & $\mathrm{D}(\mathrm{IPIX}(-3))$ & $\mathrm{D}(\mathrm{IPIX}(-4))$ & $\mathrm{D}(\mathrm{IPIX}(-5))$ & variable & $\mathrm{C}$ \\
\hline coefficient & -0.793649 & $5.39 \mathrm{E}-07$ & $6.75 \mathrm{E}-08$ & $9.98 \mathrm{E}-08$ & $1.67 \mathrm{E}-08$ & $-2.65 \mathrm{E}-08$ & coefficient & $-4.52 \mathrm{E}-05$ \\
t- statistic & {$[-95.9843]$} & {$[\mathrm{7.07755}]$} & {$[0.75962]$} & {$[1.07492]$} & {$[0.16894]$} & {$[-0.31741]$} & t- statistic & {$[-6.06026]$} \\
\hline
\end{tabular}

The quantity of coefficient of deviation from equilibrium path is equal to -0.7936 . This is statistically significant. It means; approximately $0.79 \%$ is deducted from deviation in equilibrium path of two variables in each period. Level of significance of this coefficient tells us these two variables reach to an equilibrium path in long-run. The equation of long-run equilibrium relation of two variables (IPIX and Turn over velocity ratio) is shown hereunder:

\section{Table 10}

Long-run Relation of IPIX Turn over Velocity Ratio

\begin{tabular}{cccc}
\hline variable & IPIX(-1) & TREND & C \\
\hline coefficient & $3.03 \mathrm{E}-08$ & $6.44 \mathrm{E}-09-$ & 0.000210 \\
t- statistic & {$[99.1] 119$} & {$[1.66897]$} & \\
\hline
\end{tabular}

As it can be seen from calculated quantities related to long-term relation of two variables, IPIX has significant positive effect on turn over velocity ratio of TSE listed companies during research period. In accordance with the findings of regression analysis, all three research hypotheses are accepted. In other word, closing price, transaction volume and turn over velocity ratio of shares of TSE listed companies increase as privatization IPOs lifts during research period. To design a compatible method of share issue privatization for Tehran stock market (TSE) development Delphi method experts from the required disciplines are first identified and asked to participate in the inquiry. The panel include Iranian privatization organization (IPO) specialists (13.5\%), stock market specialists in securities and exchange organization of Iran $21.6 \%$, Tehran stock exchange $21.6 \%$, investment banks, brokerage companies \& financial consulting firms and investment and finance professors(43.2\%) who are experts in the privatization and stock market functions. The number of Delphi panel is 38.

\subsection{Delphi Technique}

The implementation of Delphi questionnaire follows the Schmitt approach. First Phase Brain Storming to determine a list of share issue privatization processes and activities 
- Second Phase: Considering and recognizing different activities, pooling different ideas and shortlist the most contributive ones

- Third Phase: Ranking the most contributive activities

- Fourth Phase: Repetition to achieve unity in experts' opinions about recognized activities in second phase and the final ranking

According to majority of Delphi panel experts' responses corporate restructuring, valuation, domestic road show and market making are the most important steps during share issue privatization process. It means for success of share issue privatization causing Tehran stock market development these steps must be considered, designed and implemented more cautiously. Popularly, change in IPO price discovery from current method (English auction) to other common methods (book building, fixed price with/without underwriting) is known ineffective to design a share issue privatization model with development impact on Tehran stock exchange. The result in second round of Delphi is almost the same as first round. Share issue privatization (SIP) model for Tehran Stock Exchange developed according to the results of round \#2 is presented in Appendix.

\section{Table 11}

SIP Method for Tehran Stock Market Development in Rounds\# 1 and 2

Preferred SIP Method Via TSE by Delphi Panel

\begin{tabular}{|c|c|c|c|c|}
\hline \multicolumn{3}{|c|}{ in Round \#1 } & & \multirow{2}{*}{$\begin{array}{l}\text { in Round \#2 } \\
57.1 \% \\
\end{array}$} \\
\hline 1 & CREST & $78.40 \%$ & CREST & \\
\hline & New Rules & $48.60 \%$ & \multirow{2}{*}{ DD } & \multirow{2}{*}{$34.3 \%$} \\
\hline \multirow[t]{2}{*}{2} & DD\& Investors Confidence & $67.60 \%$ & & \\
\hline & DD\& Pre IPO Success & $48.60 \%$ & & \\
\hline \multirow[t]{2}{*}{3} & Valuation to Determine Base Price IPO & $73.00 \%$ & \multirow{2}{*}{ Valuation } & \multirow{2}{*}{$71.4 \%$} \\
\hline & Valuation and Success of IPO & $64.90 \%$ & & \\
\hline 3 & Prospectus & $59.50 \%$ & Prospectus & $42.9 \%$ \\
\hline \multirow[t]{2}{*}{4} & Domestic Road show & $56.80 \%$ & \multirow{2}{*}{ Domestic Road show } & \multirow{2}{*}{$62.9 \%$} \\
\hline & International Road show & $13.50 \%$ & & \\
\hline \multirow[t]{2}{*}{5} & Book Building & $32.40 \%$ & \multirow{2}{*}{ IPO Method } & \multirow{2}{*}{$34.3 \%$} \\
\hline & Fixed Price & $35.10 \%$ & & \\
\hline 6 & Market Making & $62.20 \%$ & Market Making & $57.1 \%$ \\
\hline 7 & Dual & $18.90 \%$ & & \\
\hline 8 & Foreigners & $32.40 \%$ & & \\
\hline
\end{tabular}

\section{Conclusion}

We begin by documenting the big impact of privatization IPOs on Tehran stock exchange (TSE). And for this purpose the initial public offering price index (IPIX) is computed. This index is calculated on the basis of Laspeyres index principles and presents the changes in privatization IPOs during research period. Then to estimate the relation of share issue privatizations on Tehran stock exchange, some of market development proxies (transaction volume, turn over velocity ratio indicating market liquidity, Tehran stock market price index (TEPIX) and closing price) are used. We tested our research hypotheses using co integration and error correction models. To increase accuracy of study, both panel data and time series of data are entered into econometric models. Afterwards to design a compatible model of share issue privatization for Tehran stock market development a two round Delphi survey was conducted. A sample of 38 financial and economic specialists are selected among experts in securities and exchange organization of Iran (SEO), Tehran stock exchange (TSE), Iranian privatization organization (IPO), Investment banks and finance professors. They all hold master's and doctorate degrees in their disciplines. Prospective participates understood that they would complete two rounds of surveys at one month interval. The study was conducted during 2008-2011. In the beginning, participants received through mail the first questionnaire comprising 10 questions about the relation of share issue privatization and Tehran stock market development and 15 questions asking about actions during share issue privatization contributing Tehran stock market development. 
After one month the second questionnaire was mailed to them, comprising 7 questions about the sequence and degree of importance of share issue privatization steps for Tehran stock market development. The results of statistical study shows that initial public offering price index and Tehran stock exchange development proxies have a correlated positive relation during 2008-2011. To test research hypotheses, panel row data are entered into co integration and error correction models.

The results show that implementing a standard share issue privatization model focusing more carefully on corporate restructuring, valuation, market making and road show steps, leads to Tehran stock exchange development. This seems sensible, because a comprehensive corporate restructuring makes the state owned enterprise subjecting to privatization, more efficient and therefore more profitable. Market making activities decline liquidity risk of privatized companies and simultaneously acts as a motivator to target investors. There is a tight correlation between the outputs of due diligence programs and valuation of state owned enterprise. The value determined for enterprise reflects its past performance, future plans and present status and therefore transmits loads of information to potential investors. Road show sessions, as a means to estimate market capacity for new offerings and to stimulate potential investors, plays a critical role in success of a share issue privatization. As it is shown in the table, its importance in success of share issue privatization and stock market development is estimated up to 63\% by Delphi panel.

Table 12

Distinguished Share Issue Privatization Steps for TSE Development by Delphi Panel\#2

\begin{tabular}{rcr}
\hline 1 & Corporate Restructuring(CREST) & 57.1 \\
2 & Valuation & 71.4 \\
3 & Domestic Road show & 62.9 \\
4 & Market Making & 57.1 \\
\hline
\end{tabular}

However there are some limitations like lengthy process of share issue privatizations in Iran, sanction atmosphere preventing foreign investors to participate in share issue privatizations in Iran and lack of formal due diligence organizations in Iran. The other problem is that although the best method of market making is concentrated quote driven (or price discovery), the dominant market making mechanism in Tehran stock exchange is non-concentrated order driven one. This is due to transaction system of Tehran stock exchange which is Euronext and its software which is PAM.

Proposed research areas are synchronization of regulations of stock exchange and privatization and review of its role in stock exchange development, studying behavioral pattern of investors in share issue privatizations and share offerings of family firms and finally capacity building in capital market to increase share issue privatization.

\section{References}

Amihud, Y. et al. (1997), “Market Microstructures and Securities Value”, Journal of Financial Economics 45, 365-390.

Asian Development Bank (ADB) (2001). Special Evaluation Study on the Privatization of Public Sector Enterprises: Lessons for Developing Countries.

Bortolotti, B., Fantini, M., \& Siniscalco, D. (2004). Privatisation around the world: evidence from panel data. Journal of Public Economics, 88(102), 305-332.

Boubakri, N., Cosset, J. \& Guedhami, O. (2008). Privatization in Developing Countries: Performance and Ownership Effects. Development Policy Review, 26(3), 275-308.

Bochner , S. E., \& Finseth, E. J. (2004). Guide To The Initial Public Offering. Merrill Corporation.

Boutchkova, M. \& Megginson, W. (2000). Privatization and the rise of Global Capital Markets. Journal of Financial Management 29, 31-76.

Brooks, C. (2008). Introductory Econometrics for Finance. Cambridge University Press.

Chiesa, G. \& Nicodana, G. (2003). Privatization and Financial Market Development: Theoretical Issues. FEEM Working Paper. 
Dalsenius, M. (2007). Effects of Stock Market Liquidity on Growth: Empirics and Theory. Working Paper, Uppsala University.

Damodaran, A. (2002). Investment valuation; tools and techniques for determining the value of any asset. New York, Published in John Wiley\& Sons Inc.

Dewenter, K.L \& Malatesta, P.H. (1997). Public Offerings of State-owned Enterprises: An International Comparison. Journal of Finance, 52, 1659-1679.

Doidge, C., Karolyi, G.A., \& Stulz, R. M. (2004). Why are foreign firms listed in the U.S. worth more?. Journal of Financial Economics, 71, 205-238.

Domowitz, I., J. Glen, \& A. Madhavan (1998). International Cross Listing and Order Flow Migration: Evidence from an Emerging Market. Journal of Finance, 53, 2001-2027.

Engle, R. F., Granger, C. W. J. (1987). Co-integration and error correction: Representation, estimation and testing. Econometrica, 55(2), 251-276.

FEEM (2002). Privatization and Financial Market Development. Research Report.

Filipovic A. (2005). Impact of privatization on economic growth. Political Economy, 14, August, pp1

Fondazione Eni Enrico Mattei (FEEM) (2002). Privatization and Financial Market Development. Research Project Report.

Glosten L.R. \& Milgrom, P. R. (1985). Bid, Ask and Transaction Prices in a Specialist Market with Heterogeneously Informed Traders. Journal of Financial Economics, 14(1), 71-100.

Geddes, Ross (2003). IPO and Equity Offerings. Butterworth-Heinemann - The Securities Institute.

Gordon, J.T. (1994). The Delfi Method. Futures Research Methodology-V3.0.

Guriev, S. \& Megginson, W. (2005). Privatization what have we learned?. ABCDE Conference- St Petersberg.

Hendry, D., Pagan, A.R. \& Sargan, J. (1984). Dynamic specification' in Z. Griliches, M.D. Intriligator (eds), Handbook of Econometrics. North-Holland, Amsterdam, pp. 1023-1100.

Hendry, D.F., \& Sternberg, T.V. (1981). Liquidity and inflation effects on consumers' expenditure. In: Deaton _Ed.., Essays in the Theory and Measurement of Consumer's Behavior. University Press, Cambridge, [8]24.

IOSCO. (2007). Factors Influencing Liquidity in Emerging Markets.

Iranian Privatization Organization, Performance Report 2002-10.

Iranian Privatization Organization (2004). Iran, Summary of Privatization Process, IPO Performance Report, Iran.

Jones, S. L., Megginson, W. L., Robert, C. N., \& Netter , J. M. (1999). Share issue privatizations as financial means to political and economic ends. Journal of Financial Economics, 53, 217-253.

Kikeri, S. \& Nellis, J. (2002). Lessons from Privatization in Developing Countries. Working Paper, World Bank.

Lombardo, D. \& Pagano, M. (2000). Legal Determinants of the Return on Equity. Working Paper, Stanford University.

Megginson, W. L. \& Netter, J. M. (2001). From State to Market: A Survey of Empirical Studies on Privatization. Journal of Economic Literature 59, 321-389.

Megginson, W. L. \& Boutchkova, M. (2000). The impact of Privatization on Capital Market Development and Individual Share Ownership. FEEM Working Paper.

Megginson, W. L. (2005). The Financial Economics of Privatization.Oxford University Press, Inc.

National Iranian Industries Organization, Performance Report 1991-2000.

Naceur, S.B., Ghazouani, S., \& Omran, M., (2007). The determinants of stock market development in the Middle-Eastern and North African region. Managerial Finance, 33(7), 477-489.

Nelson, C. R. \& Plosser, C. I. (1982). Trends and random walks in macroeconomic time series: some evidence and implications. Journal of Monetary Economy, 10, 139-62.

Pagano, M. (1993). The Floatation of Companies and the Stock Market. European Economic Review, 37, 1101-1125.

Perron, P. (1989). The great crash, the oil price shock, and the unit root hypothesis. Econometrica, Econometric Society, 57(6), 1361-1401,

Privatization Barometer (2010). The Privatization Barometer Report, Italy.

Ritter, J., \& Welch, I. (2002). A Review Of IPO Activity, Pricing, And Allocations. Yale International Center For Finance.

Phillips, A.W. (1957). Stabilization policy and the time forms of lagged responses. Economic Journal, 67, $265-277$

Russell D. \& MacKinnon, J. G. (1990). Regression-Based Methods for Using Control and Antithetic Variates 
in Monte Carlo Experiments. Working Papers 781, Queen's University, Department of Economics.

Subrahmaniam, S. \& Titman, S. (1999). The going public decision and the development of financial markets. Journal of Finance, 54, 1045-1082.

Soren, J. (1988). Statistical analysis of cointegration vectors. Journal of Economic Dynamics and Control, Elsevier, 12(2-3), 231-254.

Tehran Stock Market Report (2011). Stock Market Statistic, Iran.

\section{Appendix 1}

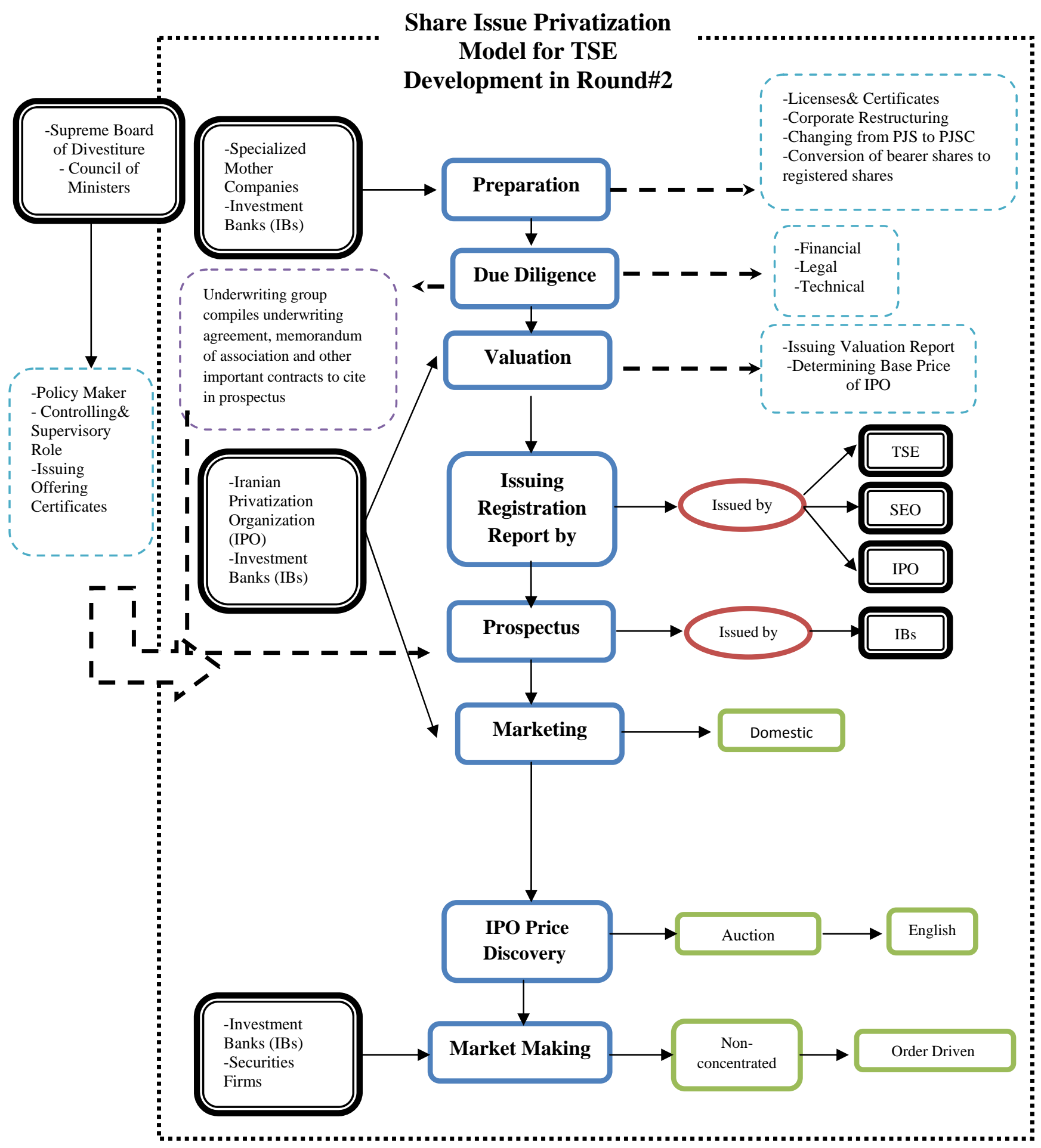

